EXPERIMENTAL STUDY

\title{
Iodine in drinking water in Denmark is bound in humic substances
}

\author{
Stig Andersen ${ }^{1,2}$, Steffen B Petersen ${ }^{2}$ and Peter Laurberg ${ }^{1}$ \\ ${ }^{1}$ Department of Endocrinology and Medicine, Aalborg Hospital and ${ }^{2}$ Department of Life Science, Aalborg University, Aalborg, Denmark \\ (Correspondence should be addressed to S Andersen, Department of Endocrinology and Medicine, Aalborg Hospital, Reberbansgade, DK-9000 Aalborg, \\ Denmark; Email: stiga@dadlnet.dk)
}

\begin{abstract}
Objective: The iodine intake level is important for the occurrence of thyroid disorders in a population. We have previously found that iodine in drinking water is related to iodine excretion but whether iodine is present as iodide or bound in other molecules remains unknown.

Design: We measured iodine in drinking water from 22 locations in Denmark. Six locations were selected by iodine content for further tap water analysis (Skagen $140 \mu \mathrm{g} / \mathrm{l}$, Samsoe $56 \mu \mathrm{g} / \mathrm{l}$, Nykoebing S. $50 \mu \mathrm{g} / \mathrm{l}$, Nakskov $40 \mu \mathrm{g} / \mathrm{l}$, Ringsted $38 \mu \mathrm{g} / \mathrm{l}$, Copenhagen $19 \mu \mathrm{g} / \mathrm{l})$.

Methods: HPLC size exclusion before (Skagen) and after (all sites) freeze drying and measurement of absorbance $(280 \mathrm{~nm})$ and iodine in fractions, and fluorescence spectroscopy of bulk organic matter in Skagen drinking water.

Results: Iodine content was unaltered after 3 years $(P=0.2)$. All samples contained organic molecules with characteristics similar to humic substances. Most iodine eluted with humic substances (Skagen 99\%, Ringsted 98\%, Nykoebing S. 90\%, Copenhagen 90\%, Samsoe 75\%, Nakskov 40\%). Changing $\mathrm{pH}$ and ionic strength and preincubation with iodide indicated that iodine was bound in humic substances. Humic substances may affect thyroid function but differ with geology. Geological and geochemical data agree with tap water humic substances having been released from marine deposits. Iodine is abundant in the marine environment and marine deposits are particularly rich in iodine. Correlation analysis $(r=0.85, P=0.03)$ conform to iodine in drinking water, suggesting marine humic substances at the source rock.

Conclusion: Iodine in Danish drinking water varied considerably. In drinking water with a high iodine content, the iodine mainly eluted with humic substances derived from marine source rock. We hypothesize that iodine in drinking water in general suggests coexisting humic substances of marine origin.
\end{abstract}

European Journal of Endocrinology 147 663-670

\section{Introduction}

The iodine intake level is important for the occurrence of thyroid disorders in a population, and both high and low iodine intake levels are associated with increased risk of disease $(1,2)$.

Dietary iodine content is decisive for the intake of iodine (3). Water is an ubiquitous component of the diet and ground water is an important drinking water resource in many countries. We have previously shown that the content of iodine in tap water exhibits major regional differences in Denmark (4) where more than $99 \%$ of drinking water is ground water. These differences are associated with differences in population iodine intake levels $(4,5)$ and with differences in the incidence and prevalence of thyroid disorders (6).
Tap water iodine content has been studied in many parts of the world $(4,7-12)$. It has been associated with thyroid disorders $(7-12)$ and subsurface geology $(10-12)$. However, data on whether iodine in drinking water is present as iodide anions or not are lacking (13).

Chemical analysis of natural waters has demonstrated variable amounts of organic matter. The majority of organic matter is aquatic humic substances (14-20). Humic substances are heterogeneous mixtures of organic molecules produced by decomposition of plant and animal tissues (15-17). The concentration and composition of humic substances in ground water vary between aquifers, depending on the geology and chemistry of the aquifer (16-18). Some humic substances may affect thyroid gland morphology and function when included in the diet (2123). This occurs because humic substances complex 
with or convert into antithyroid and goitrogenic compounds during degradation in the gut $(21,23)$.

The aim of our investigation was to elucidate the chemical nature of the iodine in drinking water in Denmark. Interestingly, we found that iodine was part of the humic substances.

\section{Materials and methods}

\section{Water samples}

Tap water samples were collected from 22 waterworks in Denmark for determination of iodine content (Fig. 1). The waterworks were chosen to verify low and high drinking water iodine contents compared with our previous investigation (4). Six waterworks were selected for further tap water analysis: one location with a high iodine content (three to four times sea water level) and five locations with a medium-high iodine content in tap water (approximately sea water level) (Fig. 1). Tap water was processed groundwater from five locations and, in Copenhagen, ground water mixed with up to $2 \%$ surface water. Samples were collected on 3 separate days from all locations. Furthermore, Skagen tap water was collected at 2-month intervals for 6 months, and once every year for 4 consecutive years.

At five waterworks, ground water had been treated with aeration, sedimentation and filtration. Skagen waterworks perform additional chemical coagulation before sedimentation, adsorption in granular-activated carbon contractors and tandem sand filtration. In Skagen, with the most extensive water treatment, the iodine content before water treatment (ground water) was $152.7 \mu \mathrm{g} / \mathrm{l}( \pm 4.0 \mu \mathrm{g} / \mathrm{l})$ and after water treatment it was $139.7 \mu \mathrm{g} / \mathrm{l}( \pm 5.2 \mu \mathrm{g} / \mathrm{l})$. Thus, water treatment reduced the iodine content of Skagen water by approximately $8.5 \%$.

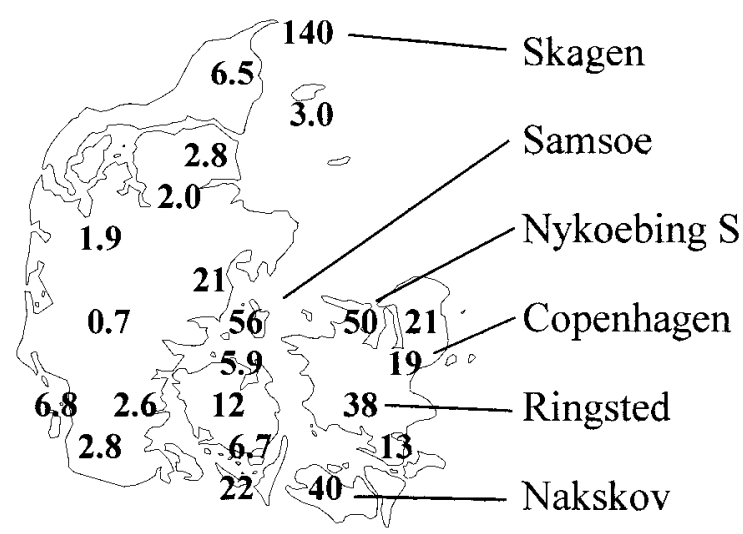

Figure 1 Map showing the iodine content $(\mu \mathrm{g} / \mathrm{l})$ of tap water collected at 22 waterworks in Denmark. Tap water from the six sites indicated were analysed further in this study.

\section{Procedures and solutions}

Tap water samples were collected in iodine-free polyethylene containers from the final tap before leaving the waterworks. Samples were kept in the dark at $4{ }^{\circ} \mathrm{C}$ until analysis. Freeze-dried samples from the six selected waterworks were stored in an oxygen-free environment until they were redissolved at 1:10 in ultrapure water from a Mili- $Q$ water purification system (Millipore, Bedford, MA, USA) for further analysis.

High performance liquid chromatography (HPLC) size exclusion was performed on an ÄKTA purifier (Amersham Pharmacia Biotech, Freiburg, Germany) using a Superose 12 HR 10/30 column (Amersham Pharmacia Biotech). This is an agarose gel with exclusion limits from 1000 to 300000 Da (limits stated by supplier), a void volume $\left(\mathrm{V}_{\mathrm{O}}\right)$ of $8.4 \mathrm{ml}$ (permeation coefficient $\mathrm{K}_{\mathrm{av}}=0$ ) and a total permeation volume $\left(\mathrm{V}_{\text {total }}\right)$ of $25.0 \mathrm{ml} \quad\left(\mathrm{K}_{\mathrm{av}}=1\right)$ (determined for the column using dextran blue and glucose). The column was calibrated with globular proteins (LMW Calibration kit; Amersham Pharmacia Biotech) for molecular weight determinations according to the log-linear method (24) and the relation was molecular weight $=$ $e^{16.8-(0.423 \times \text { Velution })}$. Five hundred microlitres of raw or resuspended tap water were added to the column after filtering through a $0.20 \mu \mathrm{m}$ membrane (Minisart; Sartorius, Göttingen, Germany) to eliminate particulate matter. Tris buffer (10 mM, pH 7.0) was the eluent in the main experiment. Elution speed was $1 \mathrm{ml} / \mathrm{min}$ and pressure was 1.45-1.52 MPa. Absorbance at $280 \mathrm{~nm}$ was registered and effluent was collected in fractions of $1.5 \mathrm{ml}$. Experiments were carried out at $21^{\circ} \mathrm{C}$ and performed in triplicate.

Findings were validated by repeated procedures on Skagen tap water at changing $\mathrm{pH}$ values (at 10.0, $9.0,8.0$ and 7.0 using a $10 \mathrm{mM}$ Tris buffer, at $\mathrm{pH} 6.0$ and 5.0 using a $10 \mathrm{mM}$ phosphate buffer, and at $\mathrm{pH}$ 4.0 using a $10 \mathrm{mM}$ citric acid buffer). Also HPLC size exclusion was performed on Skagen tap water at increased ionic strength (100 mM Tris buffer, $\mathrm{pH}$ 7.0). Furthermore, the fraction of Skagen tap water containing bulk organic substance (fraction 9) was investigated by emission fluorescence spectroscopy (PTI Fluorescence System 1.4; Photon Technology International, Lawrenceville, NJ, USA). It was excited at $280 \mathrm{~nm}$ and an emission spectrum was recorded in the range from 300 to $550 \mathrm{~nm}$.

To evaluate the effect of freeze drying on the macromolecules, HPLC size exclusion was performed on Skagen tap water with no pretreatment, after freezing and thawing, and after freeze drying and resuspending at $1: 10$. The reproducibility of the chromatograms was assessed by HPLC size exclusion on water collected on three different occasions from all sites.

Identical iodine concentrations were seen before and after filtering tap water through a $0.20 \mu \mathrm{m}$ membrane. Also, freeze drying showed no effect on the iodine 
concentration in tap water from any of the towns investigated when redissolved 1:1 in Mili-Q water (recovery 90-103\%; average 98\%).

Twenty millilitres of Skagen tap water (containing $2.8 \mu \mathrm{g}$ iodine) were mixed with $1 \mathrm{ml}$ potassium iodide $100 \mathrm{mg} / \mathrm{l}$ solution (Merck, Darmstadt, Germany) diluted to $3.0 \mathrm{mg} / \mathrm{l}$ with MiliQ water $(1 \mathrm{ml}$ contained $3 \mu \mathrm{g}$ iodide). After incubation at $21^{\circ} \mathrm{C}$ for $24 \mathrm{~h}$, HPLC size exclusion and determination of iodine in fractions were performed.

\section{Iodine determination}

Iodine was determined by the Sandell-Kolthoff reaction modified after Wilson \& van Zyl (25) as described previously (26). The principle is evaporation and alkaline ashing of the sample, followed by resuspension and measurement of iodine by the spectrophotometric detection of the catalytic role of iodine in the reduction of ceric ammonium sulfate in the presence of arsenious acid. For determination of iodine content, a $1.5 \mathrm{ml}$ sample was used giving an analytical sensitivity of
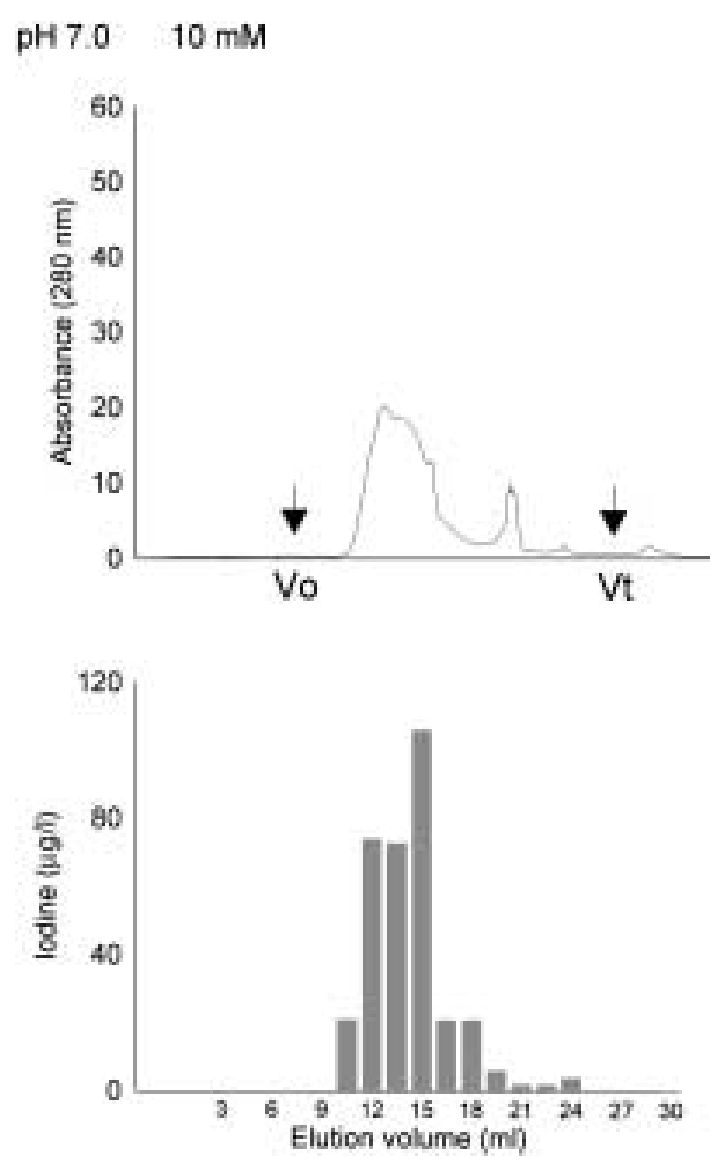

$2.0 \mu \mathrm{g} / \mathrm{l}$. The intra-assay coefficients of variation were 9.2\% (interval $2-4 \mu \mathrm{g} / \mathrm{l}, n=8$ ), 8.7\% (interval 5$9 \mu \mathrm{g} / \mathrm{l}, n=4$ ), $4.2 \%$ (interval $10-15 \mu \mathrm{g} / \mathrm{l}, n=4$ ) and $1.5 \%$ (interval $15-50 \mu \mathrm{g} / \mathrm{l}, n=5$ ). Recovery of added iodine was $>95 \%$ and not corrected for.

\section{Statistical analysis}

Tap water iodine content was compared with results from the previous study (4) by $t$-test for $[\mathrm{I}]_{1998}-$ $[\mathrm{I}]_{1995} \neq 0$ as this difference followed the normal distribution. The relation between concentrations of iodine and humic substances in tap water was estimated by Spearmann's rho test. A $P$ value of less than 0.05 was considered significant.

\section{Results}

Figure 1 shows the iodine content of drinking water collected at 22 waterworks in Denmark. The iodine concentrations in tap water at the individual sites were similar to the results of our previous study (4)
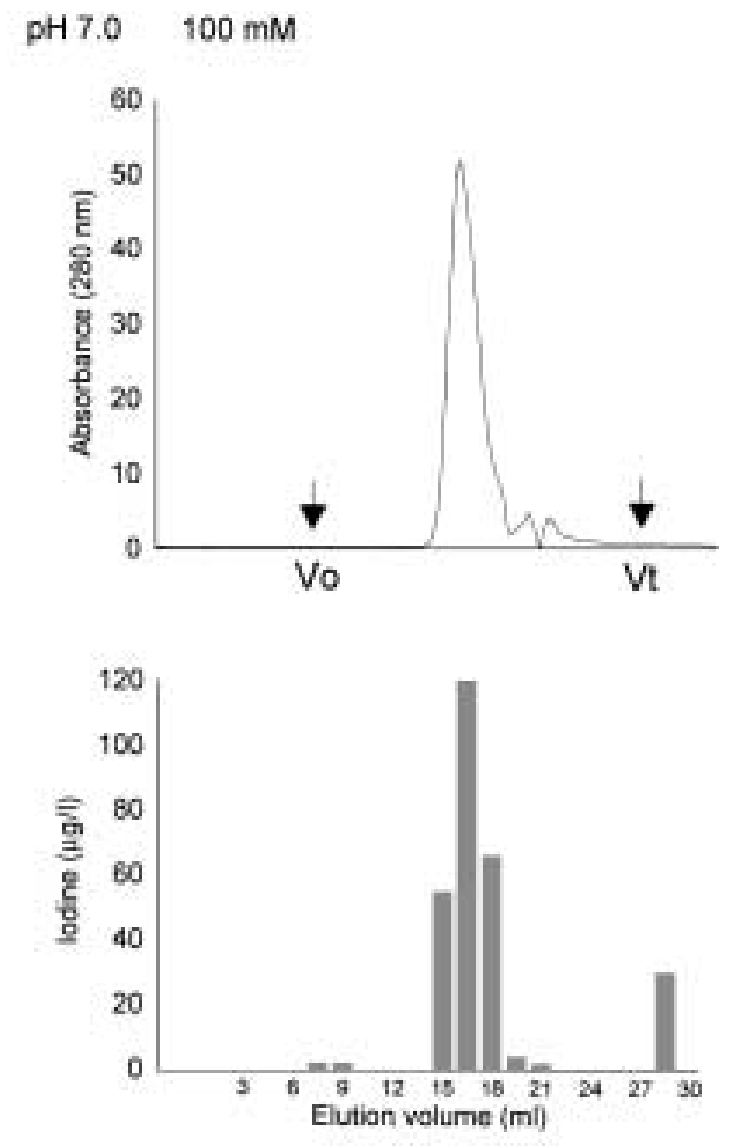

Figure 2 HPLC size exclusion performed on preconcentrated Skagen drinking water at $\mathrm{pH} 7.0$. Absorbance at $280 \mathrm{~nm}$ was registered. An increase in ionic strength from $10 \mathrm{mM}$ to $100 \mathrm{mM}$ caused a change in elution of humic substances from $\mathrm{K}_{\mathrm{av}} 0.34$ to 0.73 (upper panels) accompanied by an identical change in the elution of most iodine (lower panels). Vt, total volume. 
$(P=0.2)$. The highest iodine concentration was found in tap water from Skagen. HPLC size exclusion of Skagen tap water without pretreatment showed that iodine eluted corresponding to organic matter (data not shown).

Figure 2 shows the elution of organic matter (absorbance at $280 \mathrm{~nm}$ ) and iodine in preconcentrated Skagen tap water. A broad monomodal elution pattern with subtle shoulders and subpeaks was found. At $\mathrm{pH}$ 7.0 and ionic strength $10 \mathrm{mM}$, the main peak in absorbance eluted at approximately $\mathrm{V}_{\text {elution }} 14 \mathrm{ml}\left(\mathrm{K}_{\mathrm{av}} 0.34\right)$. Iodine eluted corresponding to this peak. Increased ionic strength from $10 \mathrm{mM}$ to $100 \mathrm{mM}$ caused a change in elution of organic matter from $\mathrm{K}_{\mathrm{av}} 0.34$ to 0.73 (molecular weight $50-3.5 \mathrm{kDa}$ ) (Fig. 2, upper panels). This was accompanied by an identical change in the elution of most iodine (Fig. 2, lower panels) while approximately $10 \%$ of the iodine eluted as low molecular weight substances (around $V_{\text {total }}$ ). Figure 3 shows the elution of organic matter and iodine in Skagen tap water at different $\mathrm{pH}$ values. Organic matter and iodine eluted simultaneously, and changing the $\mathrm{pH}$ caused a parallel change in the elution of organic matter and iodine, demonstrating that iodine in Skagen tap water was part of the organic matter.

An emission fluorescence spectrum of the fraction containing bulk organic matter from Skagen drinking water is depicted in Fig. 4. Apart from the narrow Raman scatter of water at $310 \mathrm{~nm}$, the fluorescence spectrum showed a single broad band peaking at $460 \mathrm{~nm}$. The humic substances are probably highly inhomogeneous. Thus, the fluorescence emission spectrum should be perceived as an average fluorescent signature of the humic substances. Interestingly, there was no trace of the endogenous chromophore, tryptophan, in the spectrum. However, the spectrum was

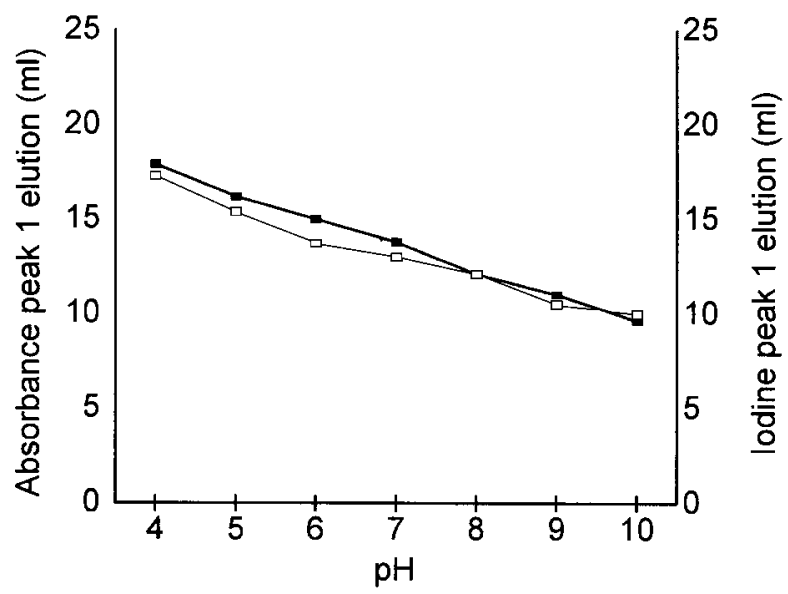

Figure 3 HPLC size exclusion of Skagen drinking water at different $\mathrm{pH}$ values. Humic substances (solid line) and iodine (broken line) eluted simultaneously, and changing the $\mathrm{pH}$ caused a parallel change in the elution. similar to spectra generally obtained from humic substances (16).

After preincubation of Skagen tap water, the iodide added eluted corresponding to $V_{\text {total }}$ (Fig. 5). The iodine content was unaltered in fractions collected corresponding to the elution of humic substances.

Figure 6 shows HPLC size exclusion chromatograms of preconcentrated tap water samples from the six locations investigated further. A main peak 1 eluted at approximately $\mathrm{V}_{\text {elution }} 14 \mathrm{ml}\left(\mathrm{K}_{\mathrm{av}} 0.34\right.$ at $\mathrm{pH} 7.0$ and ionic strength $10 \mathrm{mM}$ ) in drinking water from all locations. This corresponded to a molecular size of about $50 \mathrm{kDa}$. As can be seen in Fig. 6 the quantity of iodine eluted corresponding to this peak (Skagen 99\%, Ringsted 98\%, Nykoebing S. 90\%, Copenhagen $90 \%$, Samsoe 75\%, Nakskov 40\%). In Samsoe tap water $25 \%$ and in Nakskov tap water $60 \%$ of iodine eluted corresponding to low molecular weight substances (around $V_{\text {total }}$ ).

Figure 7 illustrates the association between concentrations of iodine and humic substance in tap water from six locations. A significant correlation was seen $(r=0.85, P=0.03)$.

Freeze drying caused a narrow absorbance peak 2 to appear at $\mathrm{V}_{\text {elution }} 19.5 \mathrm{ml}$ equal to $\mathrm{K}_{\mathrm{av}} 0.67$, corresponding to molecular weight $5 \mathrm{kDa}$ (compare Figs 5 and 2, upper left). Additional changes in the chromatographic patterns obtained were small. HPLC size exclusion chromatograms were identical for tap water samples collected on 3 consecutive days at each site, and collected at Skagen every second month for 6 months and 4 consecutive years (data not shown).

\section{Discussion}

We have previously shown that the iodine content of drinking water is important for the iodine intake level of the population in Denmark (4). In the present

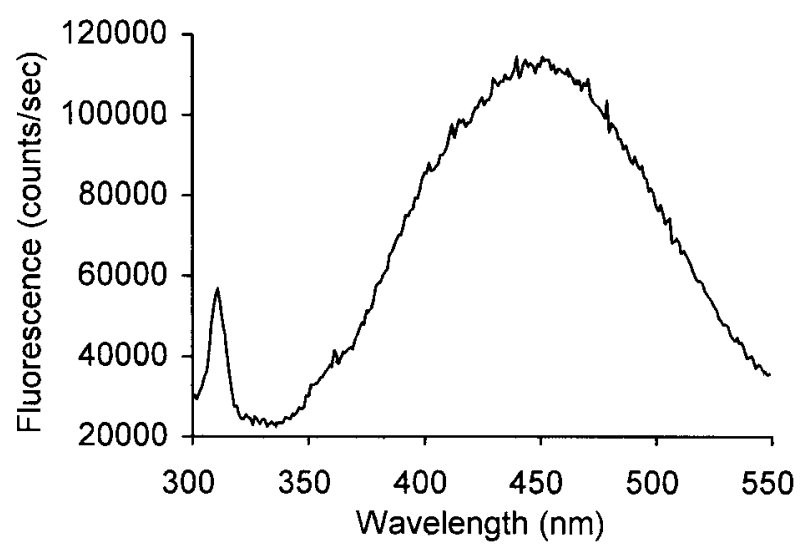

Figure 4 Emission fluorescence spectrum of organic matter in drinking water from the Skagen aquifer. Excited with monochromatic light at $280 \mathrm{~nm}$ while an emission spectrum in the range from 300 to $550 \mathrm{~nm}$ was recorded. 

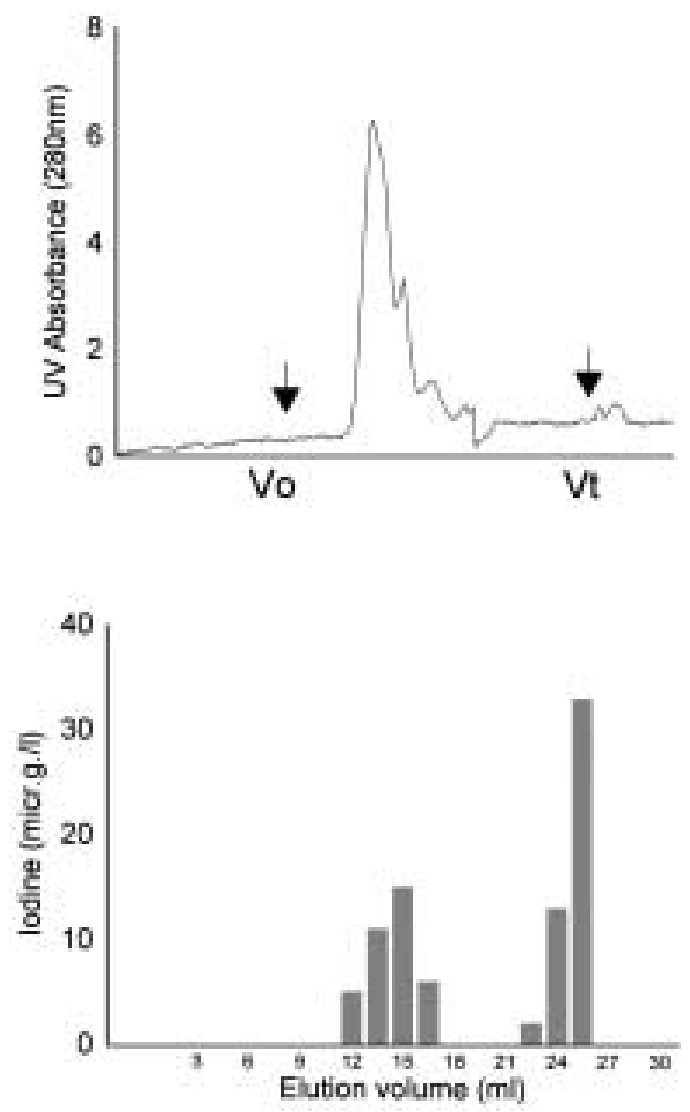

Figure 5 HPLC size exclusion elution pattern of Skagen drinking water $(20 \mathrm{ml}$ containing $2.8 \mu \mathrm{g}$ iodine) preincubated for $24 \mathrm{~h}$ with potassium iodide ( $1 \mathrm{ml}$ containing $3.0 \mu \mathrm{g}$ iodide). The iodide added eluted corresponding to $\mathrm{V}_{\text {total }}(\mathrm{Vt})$.

study, we found that the iodine content of drinking water was unaltered after 3 years and present not as iodide but mostly bound in humic substances.

Skagen tap water iodine content was about nine times higher than the average iodine content at the remaining 21 sites in Denmark $(16 \mu \mathrm{g} / \mathrm{l})$. HPLC size exclusion of untreated Skagen drinking water suggested that iodine did not exist as free iodide. This motivated further investigations.

Due to dilution during size exclusion chromatography, samples had to be preconcentrated. Freeze drying provided gentle and sufficient preconcentration of organic matter in drinking water (27) and size exclusion chromatography on a single column gave information on both molecular weight and quantity (14, 20, 28, 29). Using these techniques, we found dissolved organic matter in the drinking water from all six locations investigated, with the highest content in Skagen drinking water.

The HPLC elution pattern of organic matter in our study corresponded to humic substances $(14,17,28$, 29). Humic substances are heterogeneous mixtures of naturally occurring organic molecules. They are produced in sediments in the decay process of plant and animal tissues as an intermediate step in the eogenetic pathway from higher plant material to kerogen and eventually coal $(16,20)$. Humic substances are divided into humic acids and fulvic acids based on differences in elemental characteristics and chemical properties $(16-19,30)$. Recently, humic substances from the Skagen aquifer were characterized in detail $(18,30)$. The analyses included size exclusion chromatography, fluorescence spectroscopy, nuclear magnetic resonance spectroscopy, determination of dissolved organic carbon, amino acid and elemental composition, and isotope analyses. These investigations concluded that Skagen ground water contains fulvic acids released from 4500-year-old marine deposits (18).

We performed size exclusion chromatography and fluorescence spectroscopy of the bulk humic substances in Skagen drinking water. Our spectroscopic finding was similar to spectra generally obtained in humic substances (16) and similar to those described for fulvic acids from the Skagen aquifer (18). Size exclusion chromatography revealed different absorbances but identical retention volumes between sites. This indicated different concentrations of similar sized humic substances in tap water from all sites investigated. The unaltered findings over the 4 years of repeated sampling demonstrated the permanence and stability of iodine-containing humic substances in drinking water.

The simultaneous elution of humic substances and iodine could be coincidental. Humic substances aggregate in solution depending on $\mathrm{pH}$, ionic strength and concentration, causing variations in molecular size $(14,20,29)$. We validated our findings by repeated experiments on Skagen tap water at changing $\mathrm{pH}$ and ionic strength with unaltered concentration, and by preincubation with iodine. In all conditions, humic substances and iodine eluted simultaneously and with a constant ratio of iodine to humic substances. Also, the added iodine eluted around $V_{\text {total }}$ with an unaltered iodine/humic substances ratio. These experiments imply that iodine is part of humic substances and could suggest that the iodine was covalently bound.

A significant correlation was found between concentrations of iodine and humic substances in drinking water from the different sites investigated. However, in tap water from two locations, some of the iodine (25\% and 60\%) eluted corresponding to low molecular weight substances. The present investigations revealed no explanation for this difference as no iodine-containing substances were used and no difference in subsurface geology or water treatment was identified.

Marine deposits may be rich in iodine because iodine is assimilated and organically bound in tyrosine residues in marine organisms with concentration factors above 30000 in some algae compared with sea water $(13,31)$. Our present findings suggest that iodine in drinking water may indicate marine organic matter at the source rock and thus humic substances of marine origin in drinking water. 
brages
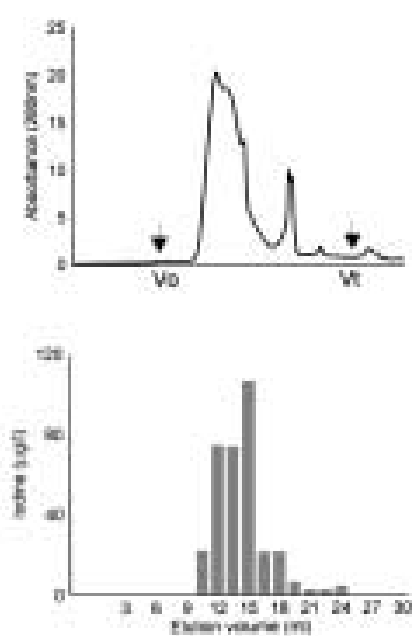

Cepertiocen
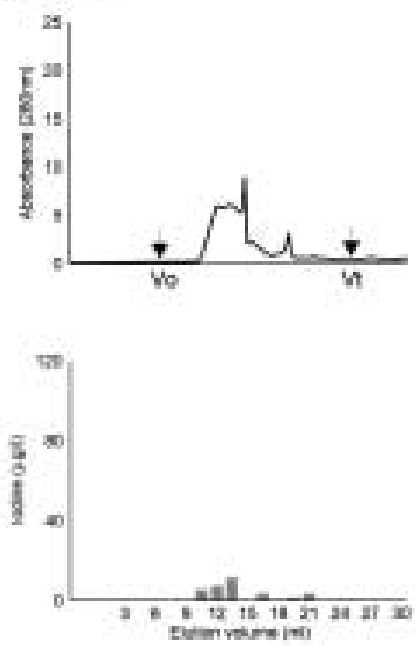

wpeceting 5
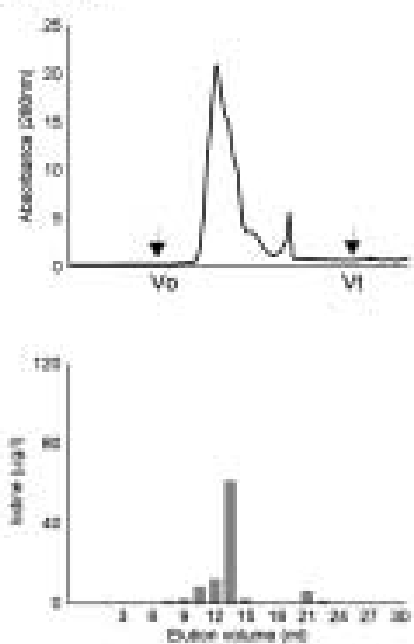

Sarece
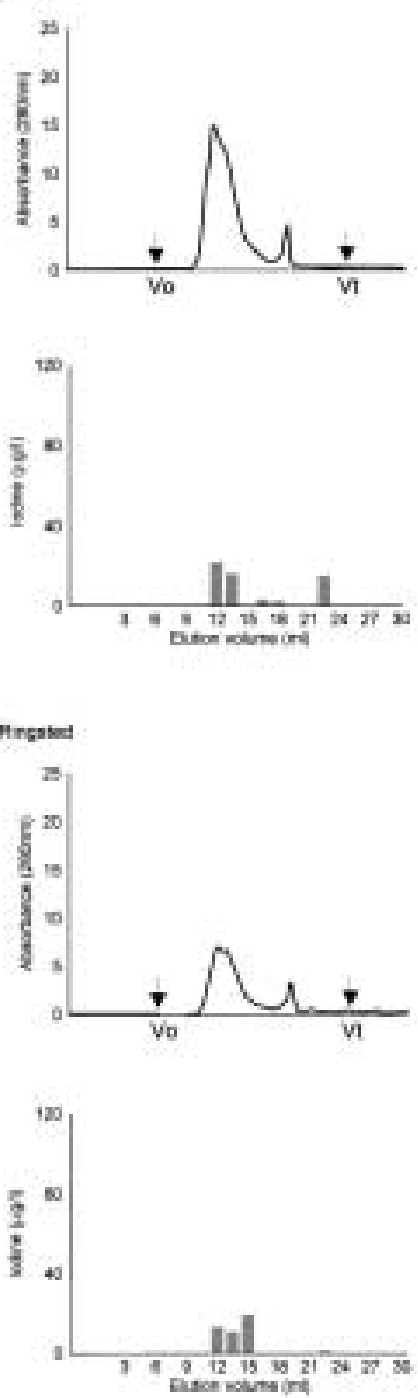

Nabakat
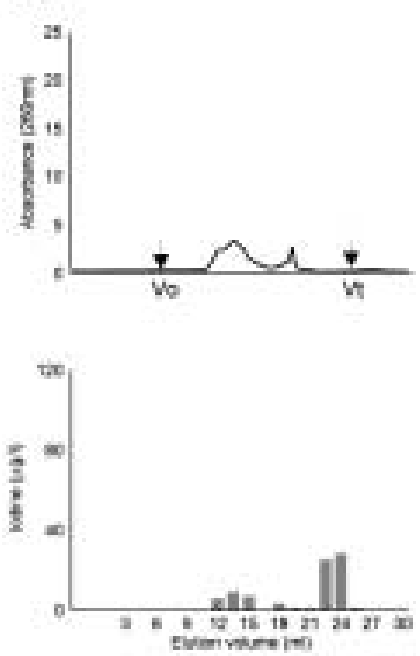

Figure 6 HPLC size exclusion (buffer: Tris $10 \mathrm{mM}, \mathrm{pH} 7.0$ ) chromatograms of drinking water samples from six locations in Denmark. At all sites, a main peak in absorbance $(280 \mathrm{~nm})$ eluted at approximately $14 \mathrm{ml}\left(\mathrm{K}_{\mathrm{av}}\right.$ $0.34)$. In water from four sites, more than $90 \%$ of iodine eluted corresponding to this peak. In Nakskov 60\% and in Samsoe 25\% of iodine eluted corresponding to low molecular weight substances. 


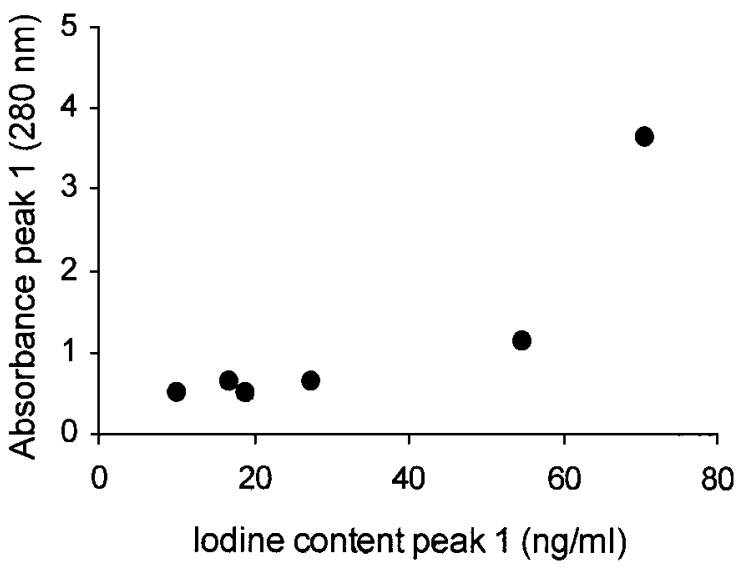

Figure 7 The relation between iodine content and the concentration of humic substances as evaluated from absorbance in HPLC size exclusion. Each dot represents one of the waterworks. Spearman's rho value was 0.85 with $P=0.03$.

Our findings are in accordance with the geological evolution of the area. Present-day Denmark was covered with ice during four ice ages over the Quartenary peroid (1.6 million years until today). Ice depressed the Earth's crust by up to several hundred meters. When the ice melted the land rose again after a delay. During this delay, sea flooded the deglaciated terrain. This was followed by an uplift, exposing large areas of sea floor, and marine deposits have been found up to $60 \mathrm{~m}$ above sea level in present-day Denmark (32). Furthermore, reclamation and shore accumulation have added to marine sediments important for ground water resources in Denmark.

We previously found that iodine in drinking water correlated positively with urinary iodine excretion in Denmark (4). This suggests that the iodine in tap water is biologically available. This is in keeping with a study showing that humic acids can be absorbed by the gastrointestinal tract, although some may leave the body via the enterohepatic circulation (33). Further studies are needed to elucidate this in detail.

In general, iodine in drinking water relates inversely to goitre prevalence $(7-11)$. However, both inconsistency and distinct exceptions were found (12, 34), and a possible explanation could be the inhibitory effect on thyroid function by some humic substances (21-23) coexisting with iodine as indicated.

In conclusion, iodine in drinking water from several locations in Denmark was part of humic substances. Our data indicate that iodine in drinking water suggests concurring humic substances of marine origin.

\section{References}

1 Gaitan E \& Dunn JT. Epidemiology of iodine deficiency. Trends in Endocrinology and Metabolism 19923 170-175.
2 Laurberg P, Bulow Pedersen I, Knudsen N, Ovesen L \& Andersen S. Environmental iodine intake affects the type of non-malignant thyroid disease. Thyroid $200111457-469$.

3 Rasmussen LB, Ovesen L, Bülow I, Jørgensen T, Knudsen N, Laurberg $\mathrm{P}$ et al. Dietary iodine intake and urinary iodine excretion in a Danish population. British Journal of Nutrition $20028761-69$.

4 Pedersen KM, Laurberg P, Nøhr S, Jørgensen A \& Andersen S. Iodine in drinking water varies by more than 100-fold in Denmark. Importance for iodine content of infant formulas. European Journal of Endocrinology 1999140 400-403.

5 Rasmussen LB. The intake of iodine assessed by various methods and the relation with thyroid diseases in two cities in Denmark. PhD Thesis 2002. University of Copenhagen.

6 Knudsen N, Bülow I, Jørgensen T, Laurberg P, Ovesen L \& Perrild $\mathrm{H}$. Comparative study of thyroid function and types of thyroid dysfunctions in two areas in Denmark with slightly different iodine status. European Journal of Endocrinology 2000143 485-491.

7 McClendon JF \& Hathaway JC. Inverse relation between iodine in food and drink and goitre, simple and exophthalmic. Journal of the American Medical Association 192482 1668-1672.

8 Hales I, Reeve T, Myhill J \& Dowda K. Goitre: seasonal fluctuations in New South Wales. Medical Journal of Australia 19691 378-380.

9 Felgentäger HJV, Gerth B \& Fanghänel S. Der jodgehalt des trinkwassers in der DDR und seine beziehung zur endemischen struma. Deutsche Gesundheitswesen 198338 1178-1182.

10 Amelsvoort V. Rural water-supply development and the recent appearance of endemic goitre. Tropical and Geographical Medicine $197123304-305$.

11 Mertz DP, Stelzer M, Heizmann M \& Koch B. Der jodgehalt des trinkwassers im endemischen kropfgebiet von Südbaden. Schweizerische Medizinische Wochenschrift 1973103 550-556.

12 Fordyce FM, Johnson CC, Navaratna URB, Appleton JD \& Dissanayake CB. Selenium and iodine in soil, rice and drinking water in relation to endemic goitre in Sri Lanka. The Science of the Total Environment 2000263 127-141.

13 Fuge R. Geochemistry of iodine in relation to iodine deficiency diseases. Environmental Geochemistry and Health $1996 \mathbf{1 1 3}$ 201-212.

14 Piccolo A, Nardi S \& Concheri G. Micelle-like conformation of humic substances as revealed by size exclusion chromatography. Chemosphere 199633 595-602.

15 Wershaw RL \& Aiken GR. Molecular size and weight measurements of humic substances. In Humic Substances in Soil, Sediment, and Water. Geochemistry, Isolation, and Characterization, pp 477-492. Eds GR Aiken, DM Mcknight \& RL Wershaw. New York: John Wiley \& Sons, 1985.

16 Thurman EM. Humic substances in groundwater. In Humic Substances in Soil, Sediment, and Water. Geochemistry, Isolation, and Characterization, pp 87-103. Eds GR Aiken, DM Mcknight \& RL Wershaw. New York: John Wiley \& Sons, 1985.

17 Calace N, D’Ascenzo G, Curtis DAS, Delfini M, Fraioli A \& Petronio BM. Chemical analysis of water of the Anticolana valley: isolation of humic compounds. Nephron 199981 93-97.

18 Grøn C, Wassenaar L \& Krog M. Origin and structures of groundwater humic substances from three Danish aquifers. Environment International 199622 519-534.

19 Pettersson C, Ephraim J \& Allard B. On the composition and properties of humic substances isolated from deep groundwater and surface waters. Organic Geochemistry 199421 443-451.

20 Nissinen TK, Miettinen IT, Martikainen PJ \& Vartiainen T. Molecular size distribution of natural organic matter in raw and drinking waters. Chemosphere 200145 865-873.

21 Gaitan E. Goitrogens in food and water. Annual Review of Nutrition $19901021-35$.

22 Seffner W. Natural water ingredients and endemic goitre - a review. Zentralblatt für Hygiene und Umweltmedizin 1995196 $381-398$. 
23 Gaitan E. Environmental natural goitrogens. In The Thyroid and Environment, pp 69-78. Eds F Péter, W Wiersinga \& U Hostalek. Stuttgart: Schattauer Verlagsgesellschaft GmbH, 2000.

24 Andrews P. Behavior of proteins related to their molecular weights over a wide range. Biochemical Journal 196596 595-606.

25 Wilson B \& van Zyl A. The estimation of iodine in thyroidal amino acids by alkaline ashing. South African Journal of Medical Science $19673270-82$.

26 Laurberg P. Thyroxine and 3,5,3'-triiodothyronine content of thyroglobulin in thyroid needle aspirates in hyperthyroidism and hypothyroidism. Journal of Clinical Endocrinology and Metabolism $198764969-974$.

27 Crompton TR. Miscellaneous preconcentration techniques. In The Analysis of Natural Waters, vol 2, pp 195-240. Ed. TR Crompton. Oxford: Oxford University Press, 1993.

28 Vartiainen T, Liimatainen A \& Kauranen P. The use of TSK size exclusion columns in determination of the quality and quantity of humus in raw waters and drinking waters. Science of the Total Environment $1987 \mathbf{6 2} 75-84$.

29 Becher G, Carlberg GE, Gjessing ET, Hongslo JK \& Monarca S. High performance size exclusion chromatography of chlorinated natural humic water and mutagenicity studies using the microscale fluctuation assay. Environmental Science and Technology $198519422-426$.

30 Grøn C. Organic halogens in Danish groundwaters. In Lecture Notes in Earth Sciences, pp 495-506. Eds B Allard, H Borén \& A Grimvall. Berlin: Springer Verlag, 1991.

31 Tong W \& Chaikoff IL. Metabolism of ${ }^{131}$ I by the marine alga, Nereocystis leutkana. Journal of Biological Chemistry 1955215 473-484.

32 Larsen G. Denmark - geography and the environment - geology. www.um.dk/english/danmark/danmarksbog/kap5/5.asp. Accessed 11 March 2002.

33 Visser SA. Some biological effects of humic acids in the rat. Acta Biologica et Medica Germanica 197331 569-581.

34 Gaitan E. Endemic goiter in western Colombia. Ecology of Disease $19832295-308$.

Received 8 May 2002

Accepted 16 July 2002 